\title{
PERSEPSI RISIKO PENUMPANG PESAWAT TERBANG
}

\author{
Mona Lestari $^{1 *}$, Annisa Rahmawaty ${ }^{2}$, Fenny Etrawati ${ }^{3}$, Nova Apriza Cahyani, \\ Shinta Dwi Kasih ${ }^{5}$, Masayu Gemala Rabiah ${ }^{6}, \operatorname{Reza} \operatorname{Ardiansyah}^{7}$ \\ ${ }^{1}$ Peminatan Keselamatan dan Kesehatan Kerja, Program Studi Ilmu Kesehatan \\ Masyarakat, Fakultas Kesehatan Masyarakat Universitas Sriwijaya \\ Corresponding Email: ${ }^{1}$ mona_lestari@fkm.unsri.ac.id \\ ${ }^{2,3}$ Peminatan Promosi Kesehatan, Program Studi Ilmu Kesehatan Masyarakat, Fakultas \\ Kesehatan Masyarakat Universitas Sriwijaya \\ Email: ${ }^{2}$ annisa.rahmawaty@gmail.com, ${ }^{3}$ fenny.etrawati@ gmail.com \\ ${ }^{4,5,6,7}$ Program Studi Ilmu Kesehatan Masyarakat, Fakultas Kesehatan Masyarakat \\ Universitas Sriwijaya \\ Email: ${ }^{4}$ novaapriza@gmail.com, ${ }^{5}$ dwikasihshinta@gmail.com, \\ ${ }^{6}$ masayugemalarabiah@gmail.com, ${ }^{7}$ reza.ardiansyah221@gmail.com
}

\begin{abstract}
Abstrak
Faktor manusia merupakan penyebab terbesar terjadinya kecelakaan pesawat. Melakukan tindakan tidak aman/unsafe act merupakan salah satu tindakan yang terbentuk dari persepsi risiko. Penelitian ini bertujuan untuk memperoleh gambaran persepsi risiko penumpang pesawat berdasarkan usia, jenis kelamin, dan jenis maskapai yang dipilih. Desain penelitian Cross-Sectional dengan 164 penumpang pesawat di bandara Sultan Mahmud Badaruddin II sebagai sampel. Teknik pengambilan sampel menggunakan simple random sampling. Hasil penelitian ini diketahui bahwa sebanyak 53,3\% penumpang yang berusia remaja (14-25 tahun) memiliki persepsi risiko yang kurang baik terhadap keselamatan transportasi udara. Selain itu, terdapat $48.7 \%$ penumpang yang memiliki persepsi risiko kurang baik berjenis kelamin laki-laki dan $48,5 \%$ penumpang yang tidak bergantung pada brand/jenis maskapai tertentu memiliki persepsi risiko kurang baik. Dari penelitian ini dapat ditarik kesimpulan bahwa mayoritas penumpang yang memiliki persepsi risiko keselamatan kurang baik berusia remaja (14-25 tahun), berjenis kelamin laki-laki, dan tidak bergantung pada brand tertentu.
\end{abstract}

Kata kunci : Jenis maskapai, persepsi risiko, pesawat terbang.

\begin{abstract}
Human factors are the biggest cause of aircraft accidents. Doing unsafe act is one of the actions that is formed from the perception of risk. This study aims to obtain an overview of the risk perceptions of airplane passengers based on age, gender, and the type of airline chosen. This study is a cross-sectional research with 164aircraft passengers at Sultan Mahmud Badaruddin II airport as a sample. The sampling technique uses simple random sampling. The study results consisted thatas many as $53.3 \%$ of passengers aged teenagers (14-25 years) have a poor perception of the risk of air transportation safety. In
\end{abstract}


addition, there were $48.7 \%$ of passengers who had poor risk perceptions of male sex and $48.5 \%$ of passengers who did not depend on certain brands/types of airlines having poor risk perceptions. From this study it can be concluded that the majority of passengers who have a perception of the risk of under-safety are both teenagers (14-25 years), male sex, and are not dependent on a particular brand.

Keywords: Types of airlines, risk perception, aircraft passengers.

\section{PENDAHULUAN}

Pesawat terbang merupakan moda transportasi yang paling efektif dan efisien dalam melakukan perpindahan dari satu tempat ke tempat yang lain. Namun dilain sisi, pesawat terbang juga merupakan alat transportasi yang memiliki tingkat risiko kecelakaan yang tinggi. Dari tahun 20102016, di Indonesia telah terjadi 26 insiden serius dan 15 kecelakaan (KNKT, 2016). Angka kejadian tersebut jika dipersentasekan mencapai $20 \%$ dari seluruh kejadian kecelakaan dan insiden selama 7 tahun terakhir (KNKT, 2016). Ditambah lagi, baru-baru ini telah terjadi kecelakaan pesawat lion Air yang menewaskan seluruh penumpang dan awak pesawat.

Data Komite Nasional Keselamatan Transportasi (KNKT) menyebutkan bahwa terdapat beberapa faktor penyebab kecelakaan pesawat yaitu $12,33 \%$ faktor lingkungan, $15,75 \%$ faktor teknis, 4,79\% karena fasilitas, dan $67,12 \%$ disebabkan oleh faktor kesalahan manusia (human error) (KNKT, 2016). Faktor manusia mendominasi hampir semua kejadian kecelakaan pesawat, dimana faktor manusia disini lebih menitik-beratkan pada kinerja pilot dan co-pilot dalam menjalankan pesawatnya.

Awak pesawat dalam hal ini pilot dan co-pilot tentunya telah memiliki sertifikat atau lisensi untuk mengendarai pesawat. Selain itu, menurut Rahimudin (2015) seluruh awak pesawat terutama pilot dan co-pilot secara rutin melakukan berbagai macam jenis pelatihan, seperti latihan kesiapsiagaan dalam menghadapi situasi darurat dan Crew Management Resources (CRM), dilakukan uji keterampilan secara berkala untuk memastikan mereka tetap layak menerbangkan pesawat. Prosedurprosedur diatas dimaksudkan untuk tetap memastikan keterampilan, kemampuan fisik dan psikologi mereka tetap dipertahankan dan mampu menerbangkan pesawat dengan aman.

Berdasarkan penjabaran diatas, tentunya pilot-dan co-pilot bukan satusatunya 'human error' yang menjadi penyebab paling dominan dalam suatu kejadian pesawat. Teori penyebab kecelakaan berdasarkan teori Frank Bird yang menyatakan bahwa kecelakaan terjadi karena adanya keselahan pada manajemen sistem. 'Human' yang berkontribusi dalam kejadian kecelakaan pesawat tidak semuanya murni diakibatkan karena pilot dan co-pilot sebagai pengemudi/pengendali pesawat, ada faktor lain yang turun andil dalam kejadian tersebut. Salah satunya adalah perilaku penumpang yang tidak taat prosedur disertai dengan tindakan yang tidak aman. Bukan hal yang membutuhkan data konkret untuk membuktikan bahwa perilaku penumpang pesawat yang tidak aman turut berkontribusi dalam kejadian nearmiss, insiden, dan kecelakaan pesawat.

Tindakan yang tidak aman penumpang pesawat salah satunya adalah tidak segera menonaktifkan handphone saat telah berada di dalam pesawat, segera mengaktifkan handphone saat pesawat 
masih dalam proses landing. Selain itu, tidak pedulinya penumpang akan prosedur keselamatan penerbangan yang terbukti dari sedikitnya penumpang pesawat yang memperhatikan secara seksama penjelasan prosedur keselamatan dan evakuasi yang diberikan oleh pramugari/pramugara serta tidak membaca dan mempelajari aircraft safety manual book.

Hal tersebut tercermin dalam bentuk persepsi risiko penumpang terhadap keselamatan transportasi udara. Menurut Damayanti (2000), persepsi risiko terbentuk dari suatu penerimaan rangsangan atau stimulus yang diperoleh dari berbagai sumber dan ditangkap oleh panca indera. Setelah itu akan menghasilkan respon yang sesuai dengan penilaian dan pemberian asrti terhadap stimulus tersebut. Sebelum diinterpretasi dalam bentuk persepsi, stimulus tersebut diseleksi terlebih dahulu, proses seleksi inilah yang mengakibatkan hasil interpretasi masing-masing individu berbeda-beda akibat faktor-faktor yang mempengaruhi. Sementara Inouye (2014) menjelaskan bahwa ketidakmampuan untuk memahami risiko secara teliti dapat menyebabkan tingkat toleransi risiko yang lebih tinggi dan dapat mendorong perilaku berisiko tinggi.

Persepsi risiko dapat dibedakan menjadi tinggi, sedang, dan rendah (Kershaw dkk., 2013). Persepsi risiko yang tinggi artiannya individu mempersepsikan dirinya pada situasi yang berisiko, sebaliknya persepsi risiko yang rendah menandakan bahwa individu mempersepsikan dirinya pada situasi yang tidak berisiko. Sehingga persepsi risiko penumpang dapat berbeda-beda bergantung pada faktor-faktor lain yang mempengaruhi persepsi tersebut. Oleh karena itu, penelitian ini bertujuang untuk memperoleh gambaran persepsi risiko penumpang pesawat berdasarkan usia, jenis kelamin, dan jenis maskapai yang dipilih.

\section{METODE PENELITIAN}

Penelitian ini menggunakan metode kuantitatif dengan jenis rancangan penelitian cross sectional study. Desain studi cross sectional adalah penelitian yang bertujuan untuk melihat dan mempelajari dinamika korelasi antara variabel independen terhadap variabel dependen dimana pengambilan data dari variabel tersebut dilakukan dalam sewaktu (point time approach) (Wibowo, 2014). Penelitian ini dilakukan pada tahun 2018. Populasi penelitian ini adalah seluruh penumpang pesawat terbang di Bandara Sultan Mahmud Badaruddin II Palembang Sumatera Selatan. Sampel dalam penelitian ini adalah penumpang pesawat terbang di Bandara Sultan Mahmud Badaruddin II Palembang Sumatera Selatan sebesar 164. Teknik pengambilan sampel menggunakan simple random sampling. Data yang digunakan dalam penelitian ini adalah data primer yang diperoleh secara langsung dengan menggunakan kuisioner yang telah di uji validitas dan reliabilitasnya. Analisis data yang digunakan adalah analysis univariat, yang bertujuan untuk mengetahui gambaran persepsi risiko penumpang pesawat terhadap keselamatan transportasi udara berdasarkan usia, jenis kelamin, dan jenis maskapai yang dipilih. 


\section{HASIL DAN PEMBAHASAN}

Tabel 1. Persepsi Risiko Penumpang Pesawat Terbang berdasarkan Usia, Jenis Kelamin, dan Jenis Maskapai

\begin{tabular}{|c|c|c|c|}
\hline \multirow[b]{2}{*}{ No } & \multirow[b]{2}{*}{ Variabel } & \multicolumn{2}{|c|}{ Persepsi Risiko } \\
\hline & & $\begin{array}{l}\text { Baik } \\
(85)\end{array}$ & $\begin{array}{c}\text { Kurang Baik } \\
\text { (79) }\end{array}$ \\
\hline \multirow[t]{3}{*}{1} & Usia & & \\
\hline & a. Remaja (14-25 tahun) & $28(46,7 \%)$ & $32(53,3 \%)$ \\
\hline & b. Dewasa (26-59 tahun) & $57(54,8 \%)$ & $47(45,2 \%)$ \\
\hline \multirow[t]{3}{*}{2} & Jenis Kelamin & & \\
\hline & a. Laki-Laki & $39(51,3 \%)$ & $37(48,7 \%)$ \\
\hline & b. Perempuan & $46(52,3 \%)$ & $42(47,7 \%)$ \\
\hline \multirow[t]{3}{*}{3} & Jenis Maskapai & & \\
\hline & a. Brand tertentu & $18(52,9 \%)$ & $16(47,1 \%)$ \\
\hline & b. Tidak bergantung pada brand & $67(51,5 \%)$ & $63(48,5 \%)$ \\
\hline
\end{tabular}

Persepsi merupakan proses akhir dari pengamatan suatu objek yang diawali oleh proses pengindraan, yaitu proses diterimanya stimulus oleh alat indra, kemudian individu memberi perhatian, lalu diteruskan ke otak, dan baru kemudian individu menyadari tentang sesuatu yang dinamakan persepsi. Persepsi individu dapat menyadari dan mengerti tentang keadaan lingkungan yang ada di sekitarnya maupun tentang hal yang ada dalam diri individu yang bersangkutan (Sunaryo, 2013).

Pesawat memiliki standar keamanan dan keselamatan yang tinggi. Semua awak pesawat baik pilot dan crew-nya merupakan orang-orang yang telah terlatih, bersertifikasi, dan terampil dalam tugasnya masing-masing. Penumpang pesawat mendapatkan stimulus atau informasi dari awak pesawat terkait peraturan/prosedur keselamatan selama berada di dalam pesawat. Serta setiap penumpang diwajibkan untuk mematuhi semua peraturan/prosedur keselamatan selama berada didalam pesawat. Hal inilah yang mendorong penumpang memiliki persepsi risiko yang baik terhadap keselamatan transportasi udara.

\section{Persepsi Risiko Berdasarkan Usia}

Hasil penelitian menunjukkan bahwa penumpang yang memiliki persepsi risiko kurang baik terhadap keselamatan transportasi udara lebih banyak berusia remaja (14-25 tahun) dibandingkan dengan penumpang yang berusia dewasa (26-59 tahun) yaitu sebesar 53,3\% (Tabel 1). Menurut Ahmadi (2007), faktor usia memiliki hubungan langsung dengan logika berpikir dan pengetahuan seseorang. Dengan kata lain, semakin matang usia seseorang maka biasanya akan cenderung bertambah pengetahuan dan tingkat kecerdasannya. Kemampuan mengendalikan emosi psikisnya dapat mengurangi terjadnya kecelakaan.

\section{Persepsi Risiko Berdasarkan Jenis Kelamin}

Dari hasil penelitian menunjukkan bahwa penumpang yang memiliki persepsi risiko kurang baik terhadap keselamatan transportasi udara berjenis kelamin lakilaki yaitu sebanyak 48,7\% (Tabel 1). Berdasarkan teori gender yang dikemukakan oleh Taylor dkk. (2009), laki-laki disebut sebagai individu yang maskulin percaya bahwa mereka memiliki banyak atribut, minat, preferensi dan keterampilan yang oleh masyarakat biasanya diasosiasikan dengan kejantanan. Sedangkan perempuan disebut sebagai individu yang sangat feminim percaya bahwa mereka memiliki atribut, minat, preferensi dan keterampilan yang 
diasosiasikan dengan feminitas. Selain itu harga diri juga dapat mempengaruhi lakilaki dalam mengambil risiko dalam setiap tindakan yang dilakukan. Harga diri adalah bagaimana orang menilai dimensi maskulinitas psikologis, dimana laki-laki cenderung memiliki harga diri yang tinggi dibandingkan dengan perempuan dalam hal kemandirian, ketegasan, dan kompetensi.

Menurut Rizkiyah dkk. (2016), perempuan merasakan risiko dengan sangat serius serta ada banyak kecemasan dan distress. Hal inilah yang menyebabkan perempuan memiliki tingkat kewaspadaan yang tinggi sehingga menjadikan perempuan memiliki persepsi risiko yang baik terhadap keselamatan penerbangan.

\section{Persepsi Risiko Berdasarkan Jenis Maskapai}

Hasil penelitian menunjukkan bahwa terdapat $48.5 \%$ penumpang yang memiliki persepsi risiko yang kurang baik tidak bergantung pada jenis/brand maskapai tertentu (Tabel 1). Setiap melakukan perjalanan dengan menggunakan alat transportasi udara, mayoritas para penumpang tidak memiliki kecenderungan untuk memilih/menggunakan jenis maskapai tertentu atas pertimbangan reputasi maskapai tersebut. Dari hasil wawancara diketahui bahwa pertimbangan penumpang dalam memiliki jenis maskapai sangat bergantung pada jadwal keberangkatan yang sesuai keinginan penumpang dan harga tiket yang diinginkan.

Keputusan pemakaian jasa maskapai penerbangan yang dimaksud dalam penelitian ini adalah perilaku konsumen yang didasarkan pada keyakinan dan rasa percaya diri yang kuat dalam mengambil suatu keputusan dalam melakukan penggunaan suatu jasa. Suatu keputusan pembelian tidak terjadi begitu saja perlu adanya proses tertentu yang dilalui oleh pelanggan. Proses tersebut dimulai dari identifikasi kebutuhan, pencarian informasi, evaluasi terhadap beberapa alternatif, dan melakukan keputusan pembelian hingga terbentuknya perilaku pasca pembelian (Willy, 2010).

Dalam hal menilai dan memberi keyakinan untuk terbangdengan aman dan selamat dengan sebuah maskapai penerbangan, maka akan kembali lagi padapersepsi penumpang penilaian objektif mereka atas faktor-faktor yang terdapat pada jasa layanan penerbangan itusendiri. Sebuah perusahaan jasa penerbangan yang mempunyai latar belakang yang baik, secara otomatis pula akan mempengaruhi persepsi dan memicu penumpang untuk menggunakan jasa layanan penerbangan dari maskapai tersebut. Dalam penelitian ini didapat hasil bahwa dengan memilih jenis maskapai ataupun tidak, penumpang memiliki persepsi yang baik terhadap keselamatan transportasi udara. Berdasarkan wawancara yang dilakukan, hal ini dikarenakan penumpang memiliki keyakinan dan kepercayaan terhadap maspakai yang digunakan, selain itu harga tiket dan jadwal keberangkatan atau tidak adanya jenis maskapai lain untuk bepergian ke suatu lokasi juga menjadi alasan penumpang tidak bisa memilih jenis maskapai tertentu.

\section{KESIMPULAN}

Dari penelitian ini dapat ditarik kesimpulan bahwa penumpang yang memiliki persepsi risiko kurang baik terhadap keselamatan transportasi udara cenderung berusia remaja (14-25 tahun) $(53,3 \%)$, berjenis kelamin laki-laki $(48,7 \%)$, dan tidak bergantung pada brand/jenis maskapai tertentu untuk melakukan perjalanan $(48,5 \%)$. 
UCAPAN TERIMA KASIH

Ucapan terimakasih diberikan pada Lembaga Penelitian dan Pengabdian Kepada Masyarakat (LP2M) Universitas
Sriwijaya sebagai pemberi dana pada Hibah Penelitian Sains, Teknologi dan Seni (Sateks) Bidang Ilmu Kesehatan dan Kedokteran tahun 2018.

\section{DAFTAR PUSTAKA}

Ahmadi, A. (2007). Psikologi Sosial. Penerbit Rineka Cipta, Jakarta.

Damayanti, R. (2000). Dasar-Dasar Psikologi, FKM Universitas Indonesia, Jakarta.

Inouye, J. (2014). Risk Perception: Theories, Strategies, And Next Steps. National Safety Council, 1-2.

Kershaw, Trace. S., Ethier, K. A., Niccolai, L. M., Lewis, J. B., \& Ickovics, J. R. (2003). Misperceived Risk Among Female Adolescent: Social and Psychological Factors Associated with Sexual Risk Accuracy. Health Psychology, 22 (5): 523-532.

KNKT. (2016). Data Investigasi Kecelakaan Penerbangan Tahun 2010-2016. Komite Nasional Keselamatan Transportasi, Kementerian Perhubungan Republik Indonesia.

Rahimudin. (2015). Analsiis Faktor-Faktor Penyebab Kecelakaan Pesawat Udara Komersil di Indonesia pada Tahun 2002 sampai dengan Tahun 2012. Jurnal Manajemen Dirgnatara, 8(12): 1-12.

Rizkiyah, E., Susanto, N., \& Nugroho, S. W. P. (2016). Perbedaan Persepsi Risiko Ditinjau Dari Gender pada Kegiatan Pendakian Gunung. Industrial Enginerering Online Journal. 5(4): 1-4

Sunaryo. (2013). Psikologi untuk Keperawatan Edisi 2. Penerbit Buku Kedokteran EGC, Jakarta.

Taylor, S.E \& Letitia, A. (2009). Psikologi Sosial Edisi Kedua Belas. Penerbit Kencana, Jakarta.

Wibowo, A. (2014). Metodologi Penelitian Praktis Bidang Kesehatan. Rajawali Pers, Jakarta.

Willy. (2010). Persepsi Penumpang Terhadap Risiko Keselamatan Penerbangan Pada Maskapai Penerbangan Lion Air. Tesis. Univesitas Indonesia. 